\title{
Why Are We So Similar? Post-Ottoman Urban Space in Turkey and Yugoslavia
}

\author{
Nataša Mišković
}

Why would I feel at home walking down Istanbul's nineteenth-century boulevard İstiklal Caddesi the very first time I visited the metropolis on the Bosphorus? How come it reminded me so much of Belgrade's Knez Mihailo Street? Growing up in Switzerland as the daughter of a Yugoslav (Serbian) father, I had always been fascinated when, on visits to Belgrade, my family would show me around and explain at certain instances that something looked this or that way "because of the Turks". Visiting Istanbul much later as a fully educated historian, I felt instantly at ease and enjoyed blending into the crowd, trying to communicate through the countless words which are identical in Serbian, Bosnian and Turkish because of their joint past in the millennia-old Byzantine-Ottoman space. Beyond the usual culprits such as language, food and crafts, similarities and common roots are not easily detectable. Memory contested by national master narratives, different gazes and an equally outdated and demanding administrative language-the Ottoman-obstruct access to further research with more or less intent (Kaser 2013, 2011).

A large research project at the University of Basel, financed by the Swiss National Science Foundation between 2013 and 2018, provided me the unique opportunity to study the above questions 
through an innovative visual approach. ${ }^{1}$ The following offers a brief insight into this project and some reflections on its findings. Focusing on four cities in two Ottoman successor states founded after World War I, the Republic of Turkey and the Kingdom of Serbs, Croats and Slovenes (the Kingdom of Yugoslavia after 1929), we explored how once-Ottoman urban societies changed in the decades after the dissolution of the Empire: how did people reinvent life under their new national regimes? Which aspects of everyday life were visibly affected by the impacts of war and national modernity? And which aspects continued as before, or evolved at a much slower pace? Belgrade, the Serbian and later Yugoslav capital, and Sarajevo, the principal town of Bosnia, had belonged to the Ottoman Empire until 1878 and 1908, respectively. They retained their character against the large-scale modernizing goals of their pre-1918 authorities in different ways: in Belgrade, the authorities built a modern, European-style city centre on the ruins of the Ottoman old town (Mišković 2008). Knez Mihailo Street was constructed during the same period as elegant Grande Rue de Péra, the famous boulevard in the Greek-Levantine quarter of Istanbul, renamed İstiklal Caddesi after 1923.

Sarajevo, under Habsburg rule between 1878 and 1918, received a sanitized "čaršija" (trade quarter of an Ottoman town) next to a brand-new city centre around Marijin dvor (Marienhof). The Austrians did not touch the Muslim landlords' privileges, which enabled the latter to conserve their traditional Ottoman lifestyle. In Belgrade, as in Sarajevo, everyday life around the old market continued as ever, maintaining the "longue durée" of the

1 PP00P1_176983 - Exploring Post-Ottoman Cities through the Photoo graphic Lens: New Approaches to Lifeworld Research in Turkey and Yugoslavia, 1920s and 1930s (acronym: SIBA). See https://nahoststudien. philhist.unibas.ch/de/forschung/forschungsprojekte/siba. 


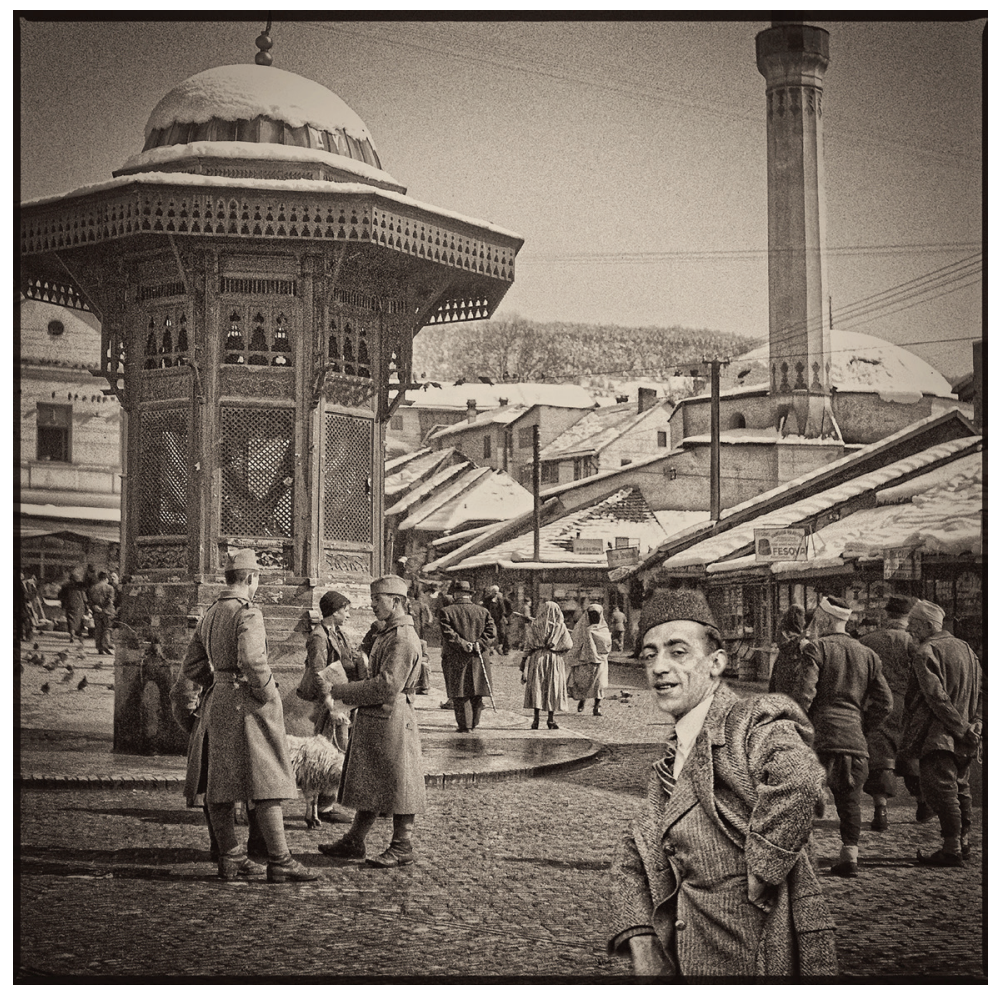

Figure 1: Photographer Mr Halačević in Baščaršija, Sarajevo 1939. Portrait by Alija M. Akšamija. Mehmed A. Akšamija Collection (siba.4854).

Byzantine-Ottoman trade micro-cosmos and contributing to the imperial phantom borders which inconspicuously continued to structure once-Ottoman space (Hirschhausen et al. 2019; Stoianovich 1967). In the new Republic of Turkey, secular leader Mustafa Kemal (later called Atatürk) invested huge amounts of money and manpower to turn Ankara, this ancient, impoverished "kasaba" (fortified market town) at the crossroads of the central Anatolian plain, into a model twentieth-century city (GIA 2010; Kezer 2015). Istanbul, the ancient metropole of the Byzantine-Ottoman empire, occupied by Allied forces between 1918 and 1923, was left defeated, dishonoured and neglected throughout the 1920s (Keyder 2008). 


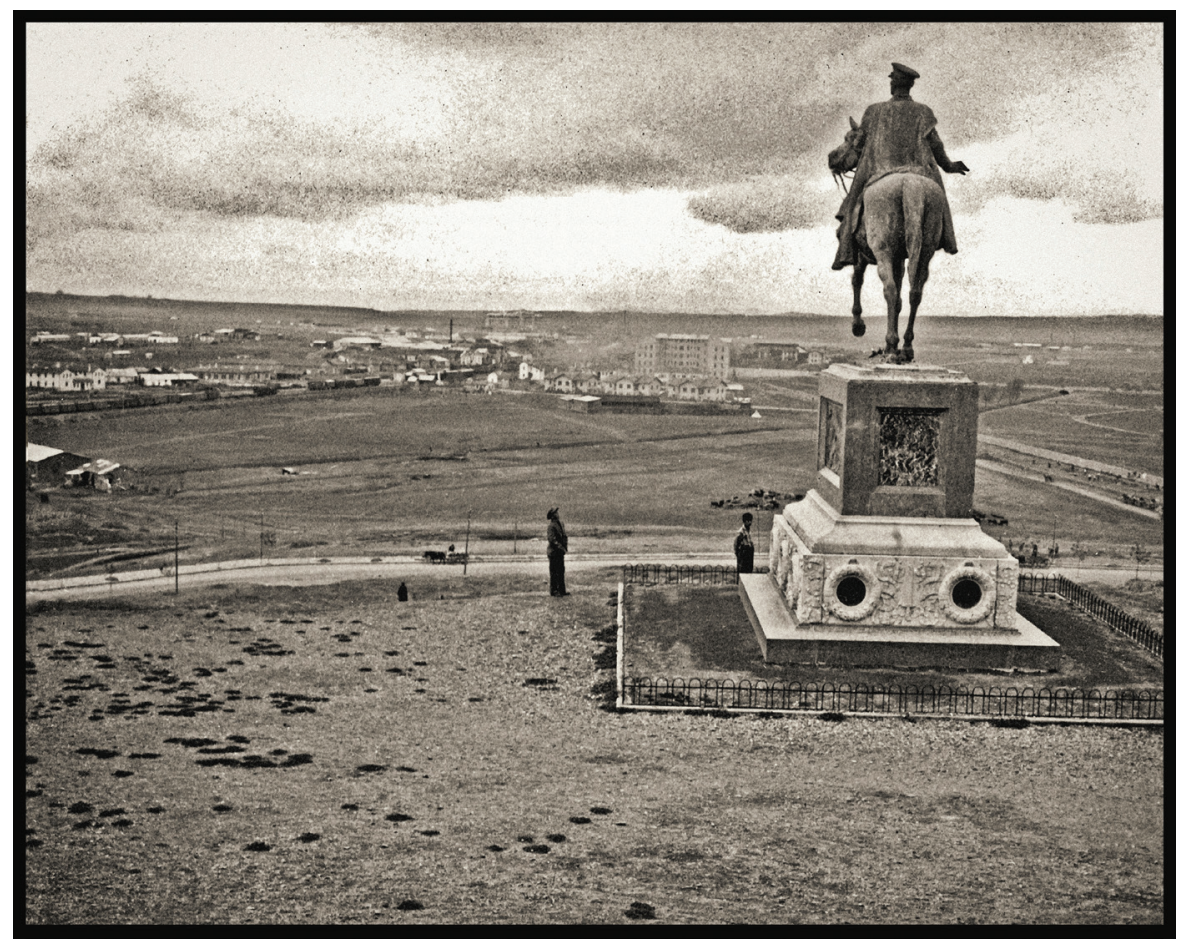

Figure 2: The Atatürk Monument in front of the Museum of Ethnography, Ankara, ca. 1927. Cengiz Kahraman Photography Collection.

Digital intervention: Mehmed Akšamija (siba.1186).

The methodology of the SIBA project (SIBA is an acronym of Sarajevo, Istanbul, Belgrade, Ankara) builds on a database of photographs from large local daily newspapers which were able to afford their own photo reporters. In contrast to the United States of America and Britain, as well as France, Germany and Austria, the Republic of Turkey and the Kingdom of Yugoslavia boasted only a very limited number of governmental papers and private publicists who could afford the latest technology of the time: the rotary press, which was a precondition to producing modern newspapers illustrated by photographs (Holzer 2014). ${ }^{2}$

2 The technology was a huge investment even for Austrian publishing houses. See Holzer (2014, 70-76, especially 75-76). 
In Belgrade, there were two such publishing houses: Vreme (Time), close to the government, and Politika (Politics), founded by liberal Belgrade publisher Vladislav Ribnikar (1871-1914) (Đorđević 2004). In Turkey, Yunus Nadi Abalığlu (1879-1945) was a publisher and journalist and a close friend of Mustafa Kemal. He founded the papers Cumhuriyet (Republic) and Yeni Gün (New Day) and the press agency Anadolu Ajansı (Anatolian Agency) in order to support his friend's regime (Köktener 2005). The database was completed with photographic material from other sources. This includes two outstanding private collections by distinguished Istanbul photo historian Cengiz Kahraman and Sarajevo photography specialist Mehmed A. Akšamija (Akša mija 2016; Kahraman 2015), who, moreover, both agreed to contribute with their local and technical expertise.

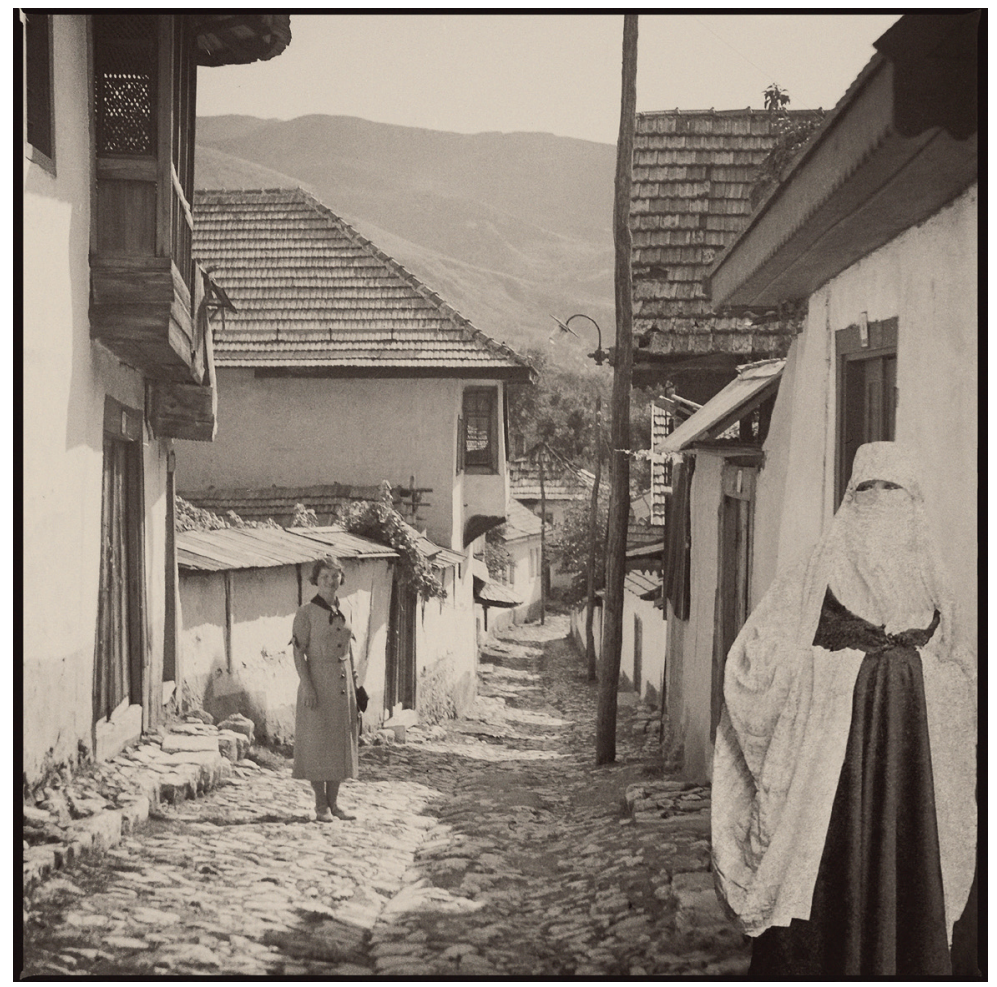

Figure 3:

Mahalla

fashion, Vratnik, Sarajevo 1939.

Mehmed A.

Akšamija

Photography

Collection.

Photographer:

Alija M.

Akšamija

(siba.4870). 
Researching and analysing the photographs was the centrepiece of the SIBA project. The procedure focused on a close comparison between the material from the archives and the published newspapers. We specifically searched for everyday situations represented in pictures from all four cities. Selected photographs were edited and published on the online portal "Visual Archive Southeastern Europe" (VASE), along with the reconstructed metadata. ${ }^{3}$ Much of this material was released to the public for the first time, notably Bosnian photographer Alija Akšamija's early work. On the basis of our analysis and editing work, we developed a travelling exhibition to present the findings and the beautiful material to a broader public.

Material quality is a decisive factor in the selection of photographs qualifying for historical analysis: if they are to serve as a basis to explore urban space of the past, they need to be clear and detailed. If they are, moreover, to serve as a foundation to narrate historical findings visually, the information they carry must be equally verifiable. The items in the SIBA database came in the form of digital scans of varying quality, depending on the materiality of the original and the skills and infrastructure of the person who had produced the scan.

Handling such diversity on an online portal required the adaptation of scan size and resolution. To produce an exhibition with enlarged photos, however, entailed digital enhancement. Sarajevo project partner Mehmed Akša mija cleaned, sharpened and enlarged roughly 250 items selected for presentation in the travelling historical exhibition.

3 Criteria for selection were copyright issues on the one hand and successful reconstruction of metadata on the other. See the Visual Archive Southeastern Europe: http://gams.uni-graz.at/vase/. For the section on the SIBA project see: http://gams.uni-graz.at/siba. 


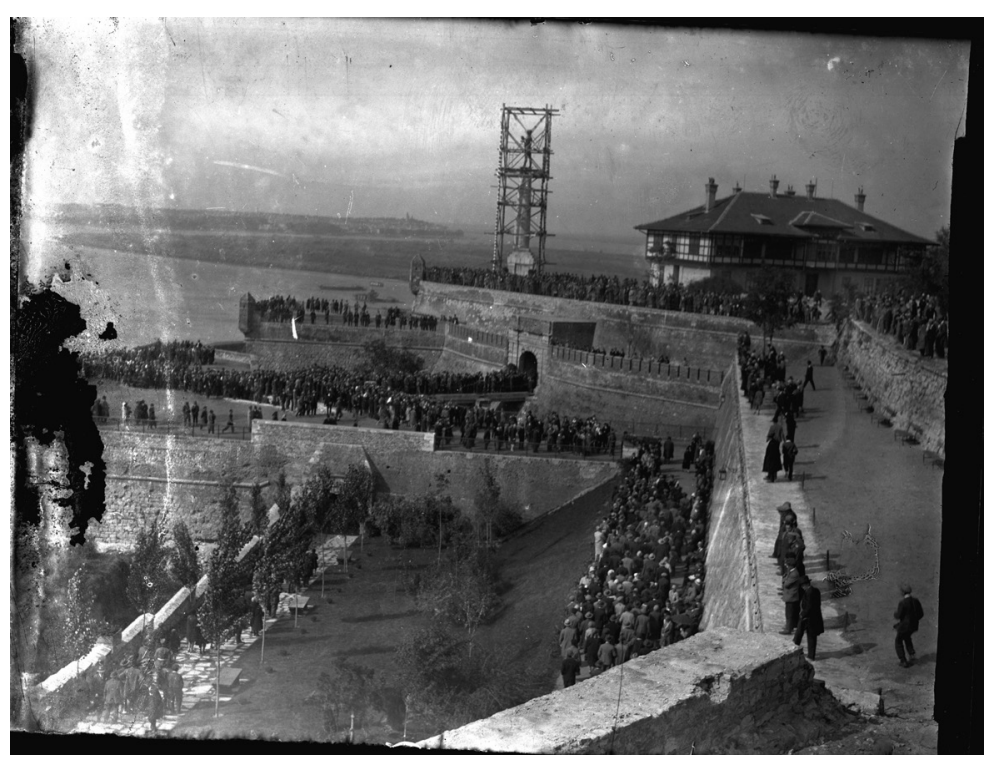

Figure 4: Rough "original" scan from a glass plate negative: unveiling of the Victor monument in Kalemegdan, Belgrade 1928. Borba fotodokumentacija. Photographer: Svetozar Grdijan (siba.4013).

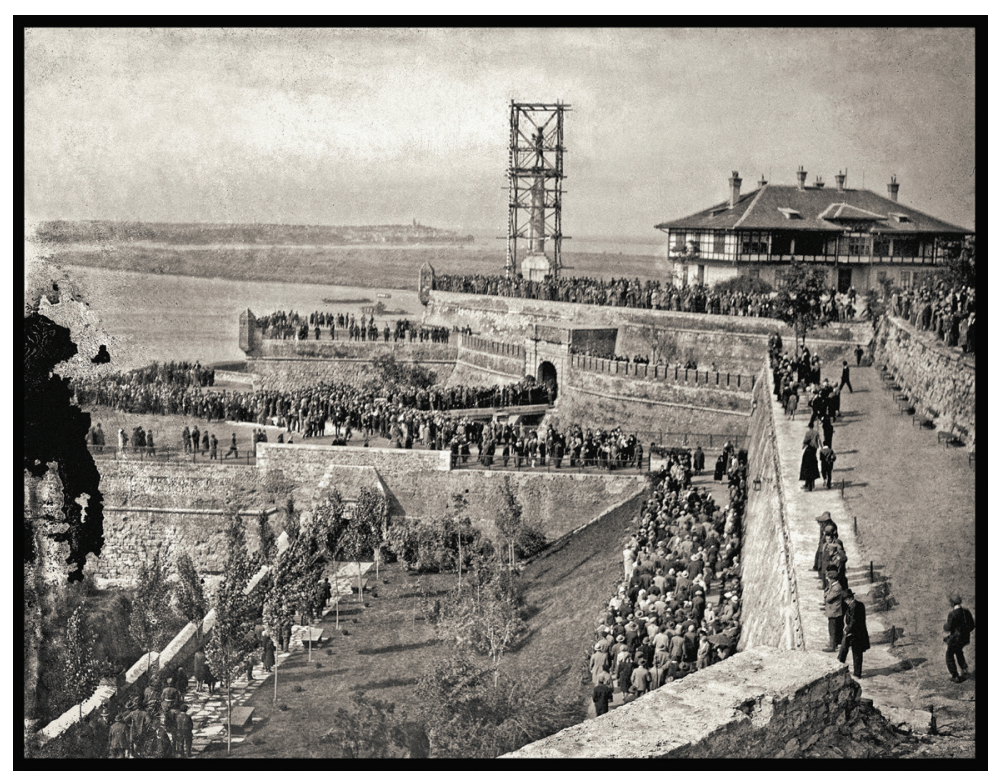

Figure 5: siba.4013 after digital restauration. 
The exhibition "Cities on the Move - Post-Ottoman", produced in cooperation with the Museum of Yugoslavia and Belgrade designers Igor and Irena Stepančić, presents the four cities-Istanbul, Ankara, Belgrade and Sarajevo-through five thematical units, which invite visitors to explore post-Ottoman legacies and national modernities as common Balkan-Anatolian urban phenomena rather than as contrasting landmark cities.

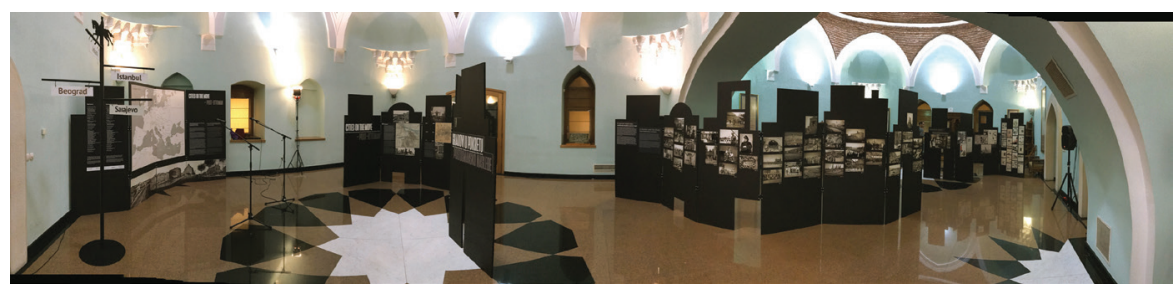

Figure 6: Exhibition Cities on the Move - Post-Ottoman at the Bosniak Institute, Sarajevo. SIBA project documentation. Photographer: Igor Stepančić.

Through the arrangement of the photographic reconstructions, which were carefully printed on "FineArt Baryta" photo paper mounted on "forex" and displayed on deep black "stadur" panels, a joint space of the past re-emerges before the visitor's eye: market scenes evoke the urban heart of Ottoman cities, dressing habits, religious holidays and leisure activities point to the common (post-)Ottoman space. Visitors have to step close and refer to a separate guide in order to learn in which city a specific photograph had been taken. Their belief in contemporary national master narratives may be challenged when exploring how postWWI monuments reinforced the divided space and new order of emerging national states.

The interactive riddle of rare, attractively presented photography proved a big success with the public and the press in Turkey, Serbia, Bosnia and beyond. Visitors readily engaged in the playful quizzing as to where a picture might come from - and 


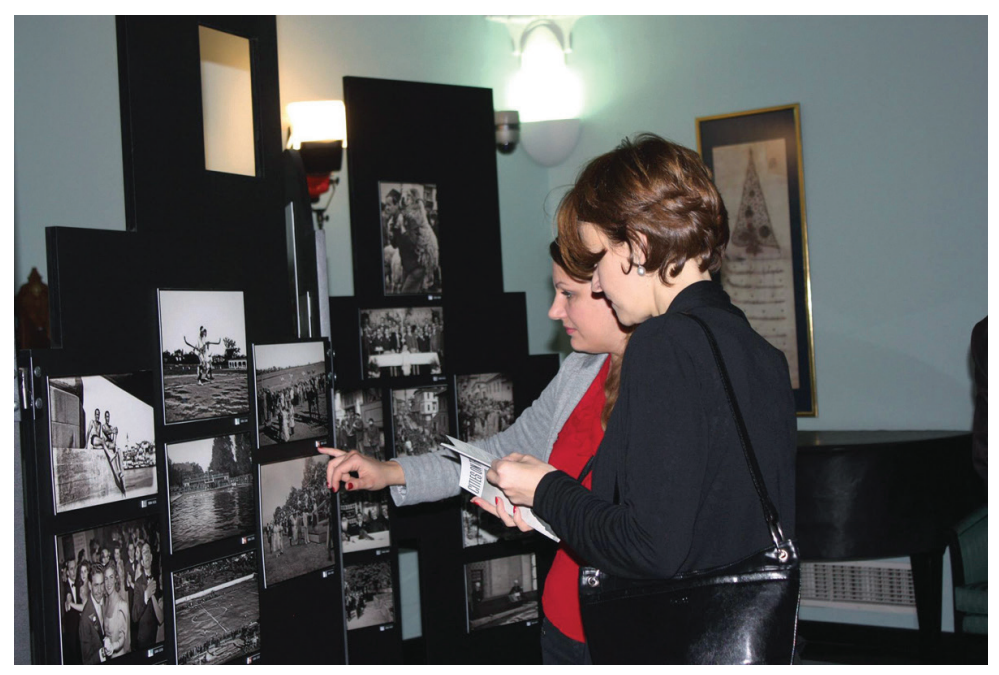

Figure 7: Visitors at the Bosniak Institute, Sarajevo. SIBA project documentation. Photograph: Bosniak Institute.

were fascinated if their guess proved wrong. Belgrade journalist Roman Jević (2017) wrote: "Sometimes you will be sure that you are looking at a building in the centre of Belgrade, then it turns out that it's Istanbul." Ljubisav Panić (2018) concluded that "each joyful, exhilarated or sorrowful face from the exhibition 'Cities on the Move' hides its own secret. Enlightened from a correct historical angle, however, the black and white actors of a past so difficult to grasp reveal that it is them alone who pulled our cities into the desired direction." Some of the pictures went viral, such as the image of two embracing beauty queens dressed in Serb and Croat national costume (Figure 8).

An isolated commentary in the exhibition guest book, which demands "improvements" according to a tunnel vision of Serbian history, underlines how much this exhibition challenges contemporary nationalist master narratives. As Panić confirms, the show enables visitors to explore their own city through the eyes and fortunes of their ancestors, but as part of a larger sphere. 
Figure 8:

Belgrade Blic tabloid reporting on the Instagram hit Miss Serbia and Miss Croatia. Photograph: Borba fotodokumentacija, by

Svetozar Grdijan, ca. 1930 (siba.4210). Report: Blic, 18 December 2018. https://

www.blic.rs/vesti/drustvo/fotografijazagrljene-misice-srbije-i-hrvatske-hit-nadrustvenim-mrezama-a-posebna/xktc7c7.

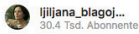

Profil ansehen

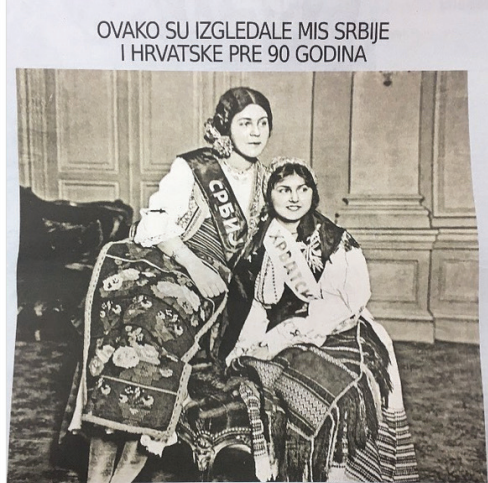

Mehr auf Instagram ansehen

\section{Q}

Gefällt 2,152 Mal

ijijana_blagojevic

Pre samo 90 godina!

alle 37 Kommentare anzeigen

Füge einen Kommentar hinzu.

Fotografija je nastala tokom dvadesetih godina prošlog veka, a u Beogradu je bila izložena pre oko godinu dana, u okviru putujuće izložbe 'Gradovi u pokretu - postotomansko nasleđe".

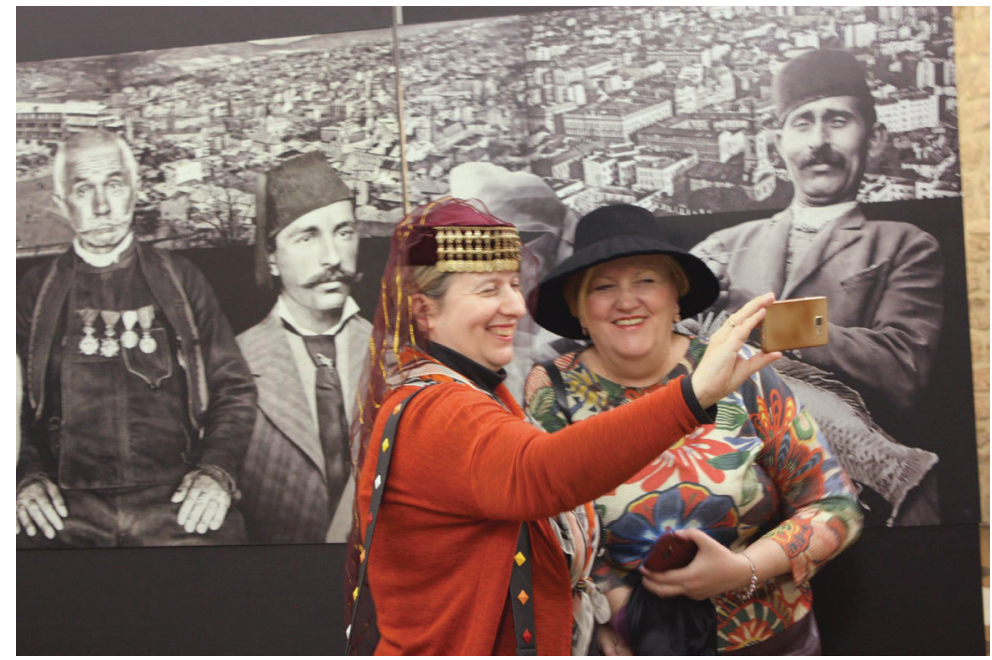

Figure 9: Visitors taking a "sibaselfie" in front of Mehmed Akšamija's photo collage. SIBA project documentation. Photograph: Bosniak Institute. 
Visitors engage with the visual sources in an emotional way, recognizing nothing less than their own family history in the pictures. In the words of another visitor, the exhibition offers "a return to the city of my birth, of my childhood" (Jelena, 22 November 2017). As Susan Sontag famously wrote, "photographs furnish evidence", and making photographs helps "people to take possession of space in which they are insecure" (Sontag 1977: 5, 9). The local press reporters' photos seem to activate memories of the visitors' own familiar past, memories which are all too often in contrast with the past as presented by national master narratives learnt at school. An excellent example of this contested past is the discussion which emerged around Figure 8: Miss Serbia and Miss Croatia, both with sashes in Cyrillic letters, were not official beauty queens but Belgrade students participating in the play "Greetings to Yugoslavia" at the royal court in 1930. Whereas most of today's commentators dwelt on the changing ideals of female beauty, others interpreted it in the context of the ongoing dispute on the use of Cyrillic letters in Croatia. Pressure to publish only pictures which are consistent with the self-image of a (national or local) society, however, exists on the institutional as much as on individual level: Photos in newspaper archives were stored in neglect rather than preserved with care. Photographer Alija Akšamija kept his Sarajevo album from 1938-1939 private, because local society rules did not allow him to expose members whose portrait he had taken, such as the ladies in Figure 3: The conservative interwar Muslim society of Bosnia still regarded photographing women as improper, the camera as bedevilled (Akšamija 2016: 20-21; Kaser 2013: 81-105). In view of all these obstacles, why should we wonder that so many visitors want to see this exhibition, engaging with it full of emotion, treating it as a sensation? 


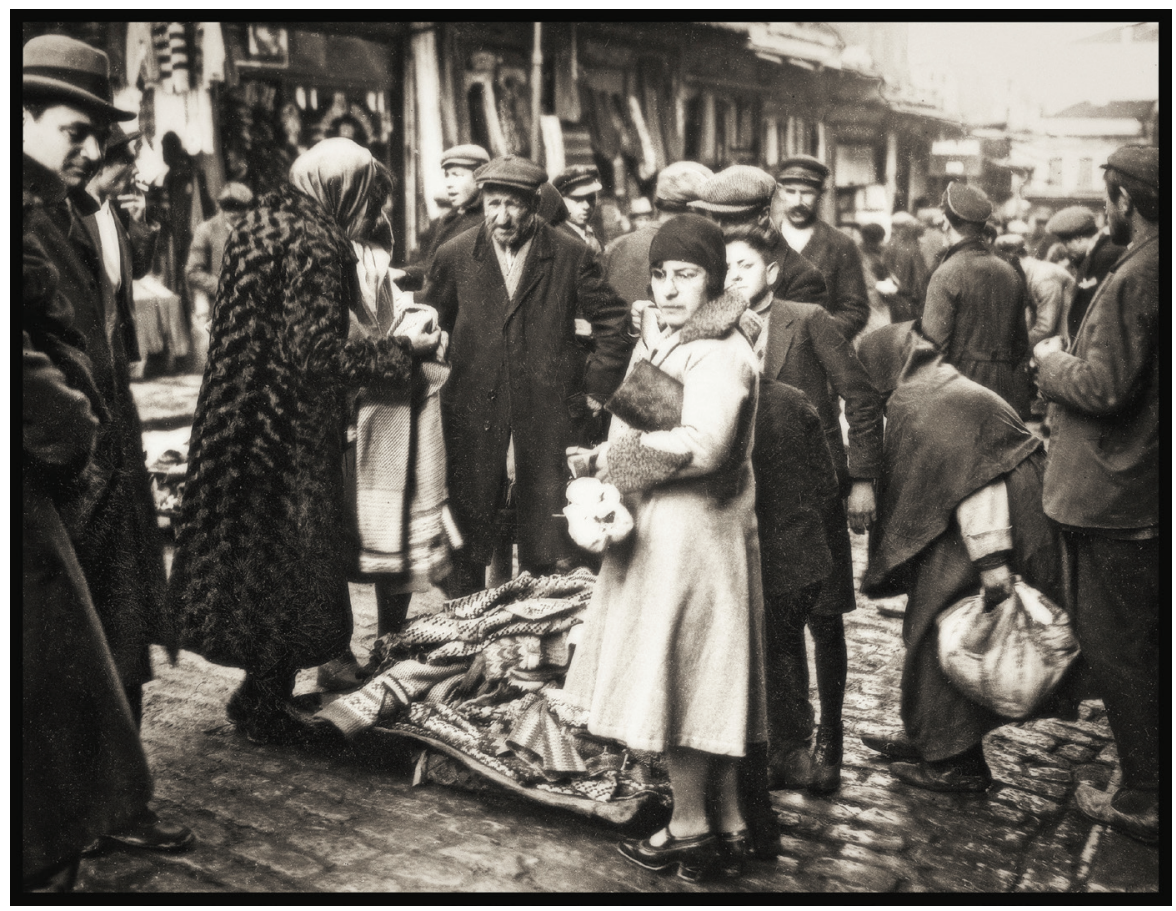

Figure 10: Holiday shopping at Mahmut Paşa, Istanbul. Cengiz Kahraman Photography Collection. Digital intervention: Mehmed Akšamija (siba.1151).

NATAŠA MIŠKOVIĆ teaches at the University of Basel. She was SNSF research professor at the Middle Eastern Studies, University of Basel from 2013 to 2018, and visiting professor at the universities of Berne and LMU Munich. She can be reached at natasa.miskovic@unibas.ch 


\section{References}

Akšamija, Mehmed A. 2016. Alija M. Akšamija: Monografija arhivografije [Alija M. Akšamija: Monograph of archivography]. Sarajevo.

Đorđević, Života. 2004. Politika: pogled na epohu, 1904-1941 [View of an Epoch]. Belgrade: Politika NM.

GIA (Goethe-Institut Ankara). 2010. Das Werden einer Hauptstadt [Becoming of a Capital]. Accessed 29 April 2019. http://www. goethe.de/ins/tr/ank/prj/urs/deindex.htm.

Hirschhausen, Béatrice von, Hannes Grandits, Claudia Kraft, Dietmar Müller and Thomas Serrier. 2019. Phantom Borders in Eastern Europe: A New Concept for Regional Research." Slavic Review 78 (2): 369-389. doi: 10.1017/sIr.2019.93.

Holzer, Anton. 2014. Rasende Reporter. Eine Kulturgeschichte des Fotojournalismus [Speedy Reporters. A Cultural History of Photo Journalism]. Darmstadt: Primus.

Jević, Roman. 2017. “Vreme kad gradovi oblače evropsko odelo [The Time when Cities Dressed in a European Suit]". Espreso, 20 November. https://www.espreso.rs/kultura/galerija/200359/ gradovi-u-pokretu-postosmansko-nasledje-vreme-kad-gradovi-oblace-evropsko-odelo-i-njihovi-stanovnici-odbacuju-orijentalne-manire.

Kahraman, Cengiz. 2015. Istanbul Kiş Günlügü 1929 ve 1954 [Winter Journal 1929 and 1954] Istanbul: Yapı Kredi Yayınları.

Kaser, Karl. 2013. Andere Blicke: Religion und visuelle Kulturen auf dem Balkan und im Nahen Osten [Different Gazes: Religion and Visual Cultures on the Balkans and in the Middle East]. Vienna: Böhlau.

Kaser, Karl. 2011. The Balkans and the Near East. Introduction to a Shared History. Vienna: LIT.

Keyder, Çağlar. 2008. "A Brief History of Istanbul”. In: The Cambridge History of Turkey, edited by Reşat Kasaba and Kate Fleet, 504-523. Cambridge: Cambridge University Press. 
Kezer, Zeynep. 2015. Building Modern Turkey: State, Space and Ideology in the Early Republic. Pittsburgh, PA: University of Pittsburgh Press.

Köktener, Aysun. 2005. Bir Gazetenin Tarihi: Cumhuriyet. Istanbul: Yapı Kredi Yayınları.

Mišković, Nataša. 2008. Basare und Boulevards: Belgrad im 19.

Jahrhundert [Bazaars and Boulevards: Belgrade in the 19th Century]. Vienna: Böhlau.

Panić, Ljubisav. 2018. “Život kakvog više nema [A Lifestyle Which Is No More]". City Magazine, 27 January. https:/citymagazine.rs/ clanak/zivot-kakvog-vise-nema-fotografije-sa-izlozbe-gradovi-u-pokretu.

Sontag, Susan. 1977. On Photography. New York: Farrar, Straus and Giroux.

Stoianovich, Traian. 1967. A Study in Balkan Civilization. New York: Knopf. 